\title{
Analisis Perencanaan Tebal Perkerasan Kaku Lajur Pengganti pada Proyek Pembangunan Jalan Tol Jakarta-Cikampek II Elevated
}

\section{(Analysis of Rigid Pavement Thickness Design of Road Widening at Jakarta- Cikampek II Elevated Toll Road Construction Project)}

\begin{abstract}
Rahmat Ardiansyah $^{1 *}$ dan Tri Sudibyo ${ }^{1}$
${ }^{1}$ Departemen Teknik Sipil dan Lingkungan, Fakultas Teknologi Pertanian, Institut Pertanian Bogor Kampus IPB Dramaga, PO BOX 220, Bogor, Jawa Barat, Indonesia

*Penulis korespondensi : Rahmatardiansyah201@gmail.com

Diterima: 31 Agustus 2019

Disetujui: 20 Desember 2019

ABSTRACT

Road widening is a construction phase of Jakarta-Cikampek II elevated Toll Road construction project. Improving the effectiveness and road service capability influence the traffic activity. This study aimed to analyze alternative rigid pavement design and thickness based on the Road Pavement Design Manual (MDPJ) 2017 and American Association of State High-way and Transportation Officials Guide for Design of Pavement Structures (AASTHO) 1993. This research was conducted on March - May 2019. Based on the obtained data, a rigid pavement design alternative using the MDPJ 2017 method showed concrete plate thickness of $305 \mathrm{~mm}$ and using the AASHTO 1993 concrete plate thickness was $320 \mathrm{~mm}$. In actual condition the concrete plate thickness was $300 \mathrm{~m}$.
\end{abstract}

Keywords : AASHTO 1993, concrete plate thickness, MDPJ 2017, road widening

\section{PENDAHULUAN}

Pembangunan Jalan Tol JakartaCikampek II elevated didasari oleh kepadatan lalu lintas yang terjadi di Jalan Tol Jakarta-Cikampek. Hal ini disebabkan oleh pertumbuhan volume lalu lintas yang melebihi rencana kapasitas ruas jalan, pertumbuhan manufaktur pada sektor industri utama, perkembangan sub koridor baru yang terjadi di Timur Jakarta, wilayah administrasi Kota Bekasi, Kabupaten Bekasi dan Kabupaten Karawang. Pembangunan Jalan Tol JakartaCikampek II elevated bertujuan untuk mempermudah pergerakan arus lalu lintas dan arus barang serta penduduk dari Jakarta menuju ke Kota Bekasi, Kabupaten Bekasi, Kabupaten Kerawang sampai Bandung, meningkatkan fungsi jaringan jalan eksternal wilayah Jawa Barat untuk mengakomodir pergerakan barang dan jasa lintas provinsi, dan mendukung pengembangan kota-kota di wilayah Provinsi Jawa Barat. Pekerjaan lajur pengganti merupakan tahap konstruksi dalam pembangunan Jalan Tol JakartaCikampek II elevated. Pembuatan lajur pengganti dilaksanakan dengan mengganti bahu jalan dan mengganti 1 lajur menjadi 4 lajur dengan panjang $6,1 \mathrm{~m}$ (penggeseran 3,6 $\mathrm{m}+$ bahu jalan 2,5 m). Lajur pengganti dibuat untuk meningkatkan efektivitas pada pembangunan jalan tol eksisting yang berdampak pada aktivitas lalu lintas yang terjadi (Huang 2004). Tahapan konstruksi pada pembuatan lajur pengganti dalam proyek pembangunan Jalan Tol JakartaCikampek II elevated meliputi pekerjaan pembersihan tempat kerja, pekerjaan tanah (galian dan timbunan), pekerjaan lapis pondasi agregat, dan pekerjaan perkerasan jalan (perkerasan kaku dan lentur).

Menurut Hamirhan

perkerasan jalan merupakan lapisan konstruksi yang dipasang diatas tanah dasar 
badan jalan pada jalur lalu lintas yang bertujuan untuk menerima dan menahan beban langsung dari lalu lintas. Perkerasan kaku merupakan lapisan beton yang berfungsi sebagai base course dan surface course pada perkerasan jalan raya dan cocok digunakan pada jalan raya yang melayani lalu lintas tinggi berkecepatan tinggi (Hardiyatmo 2011). Secara struktural kinerja perkerasan harus dipelihara agar tetap mempunyai masa layan atau umur rencana yang sesuai dengan yang dirancang sebelumnya sehingga perkerasan tersebut masih mampu menahan beban lalu lintas. Secara fungsional dapat diukur dari tingkat pelayanan suatu perkerasan yang berkaitan dengan kenyamanan pengguna jalan.

Perkerasan kaku umumnya terdiri dari tanah dasar, lapisan pondasi bawah dan pelat beton semen portland dengan atau tanpa tulangan. Perkerasan kaku cocok untuk digunakan pada jalan raya yang melayani lalu-lintas tinggi berkecepatan tinggi (Hardiyatmo 2011). Kang et al. (2010) menyatakan pentingnya pemeliharaan perkerasan telah meningkat seiring peningkatan volume kendaraan dan bebean roda meningkat dalam sistem jalan raya. Oleh karena itu, diperlukan analisis lebih lanjut terkait alternatif desain dan perencanaan tebal perkerasan jalan pada pembuatan lajur pengganti proyek pembangunan Jalan Tol JakartaCikampek II elevated untuk memberikan alternatif desain terhadap analisis kekuatan dan umur layanan jalan terhadap kondisi existing jalan.

Menurut Aris et.al (2015) peraturan dan pedoman struktur perkerasan jalan raya di Indonesia merupakan hasil modifikasi dan penyesuaian dari negara maju seperti Amerika Serikat, Inggris, dan Australia. Metode analisis perencanaan tebal perkerasan kaku pada penelitian ini mengacu pada Manual Desain Perkerasan Jalan (MDPJ) 2017 dan American Association of State High-way and Transportation Officials Guide for Design of Pavement Structures (AASTHO) 1993. Penggunaan MDPJ 2017 dan AASHTO 1993 pada penelitian ini digunakan untuk memberikan alternatif desain dan tebal perkerasan kaku pada pekerjaan pembuatan lajur pengganti dalam proyek pembangunan Jalan Tol Jakarta-Cikampek II elevated.

Tujuan penelitian ini adalah sebagai berikut :

1. Analisis alternatif desain perkerasan kaku menggunakan metode MDPJ 2017 dan AASHTO 1993 pada pembuatan lajur pengganti dalam pembangunan Jalan Tol JakartaCikampek II elevated.

2. Analisis tebal perkerasan yang dibutuhkan pada perkerasan kaku menggunakan metode MDPJ 2017 dan AASHTO 1993.

3. Analisis perbandingan tebal perkerasan kaku metode MDPJ 2017 dan AASHTO 1993 terhadap kondisi existing.

\section{METODOLOGI}

Penelitian dilakukan pada bulan Maret hingga Mei 2019. Lokasi penelitian terletak di lajur pengganti proyek pembangunan Jalan Tol Jakarta-Cikampek II elevated. Alat yang digunakan dalam rangkaian penelitian yaitu laptop/komputer yang dilengkapi Microsoft Office 2010, software AutoCAD, software ArcGIS, dan kalkulator. Bahan yang digunakan dalam penelitian ini berupa data sekunder mengenai data lalu lintas, ringkasan uji tanah, dan data desain dan perhitungan perencanann perkerasan yang diperoleh dari PT Jasa Marga (Persero) Tbk selaku pemilik proyek dan PT Waskita Karya (Persero) Tbk selaku kontraktor. Analisis perkerasan kaku dilakukan berdasarkan peraturan Manual Desain Perkerasan Jalan 
(MDPJ) 2017, American Association of State High-way and Transportation Officials Guide for Design of Pavement Structures (AASTHO) 1993, dan Pd T-14-2003 Perencanaan Tebal Perkerasan Jalan Beton Semen.

Prosedur penelitian mencakup pengambilan data sekunder, pengolahan, dan analisis tebal perkerasan kaku pada lajur pengganti pembangunan Jalan Tol JakartaCikampek II elevated. Data sekunder meliputi data lalu-lintas, uji tanah dan CBR, hidrologi, desain dan struktur perkerasan, serta dokumen rencana kerja dan syarat-syarat (RKS) yang diperoleh dari PT Jasa Marga (Persero) Tbk selaku pemilik proyek dan PT Waskita Karya (Persero) Tbk selaku kontraktor. Data desain perkerasan kaku mengacu pada peraturan MDPJ 2017, AASTHO 1993, dan Pd T-14-2003. Analisis tebal perkerasan kaku pada penelitian ini menggunakan metode MDPJ 2017, AASHTO 1993, serta Pd T-14-2003. Diagram alir pelaksanaan penelitian disajikan pada Gambar 1.

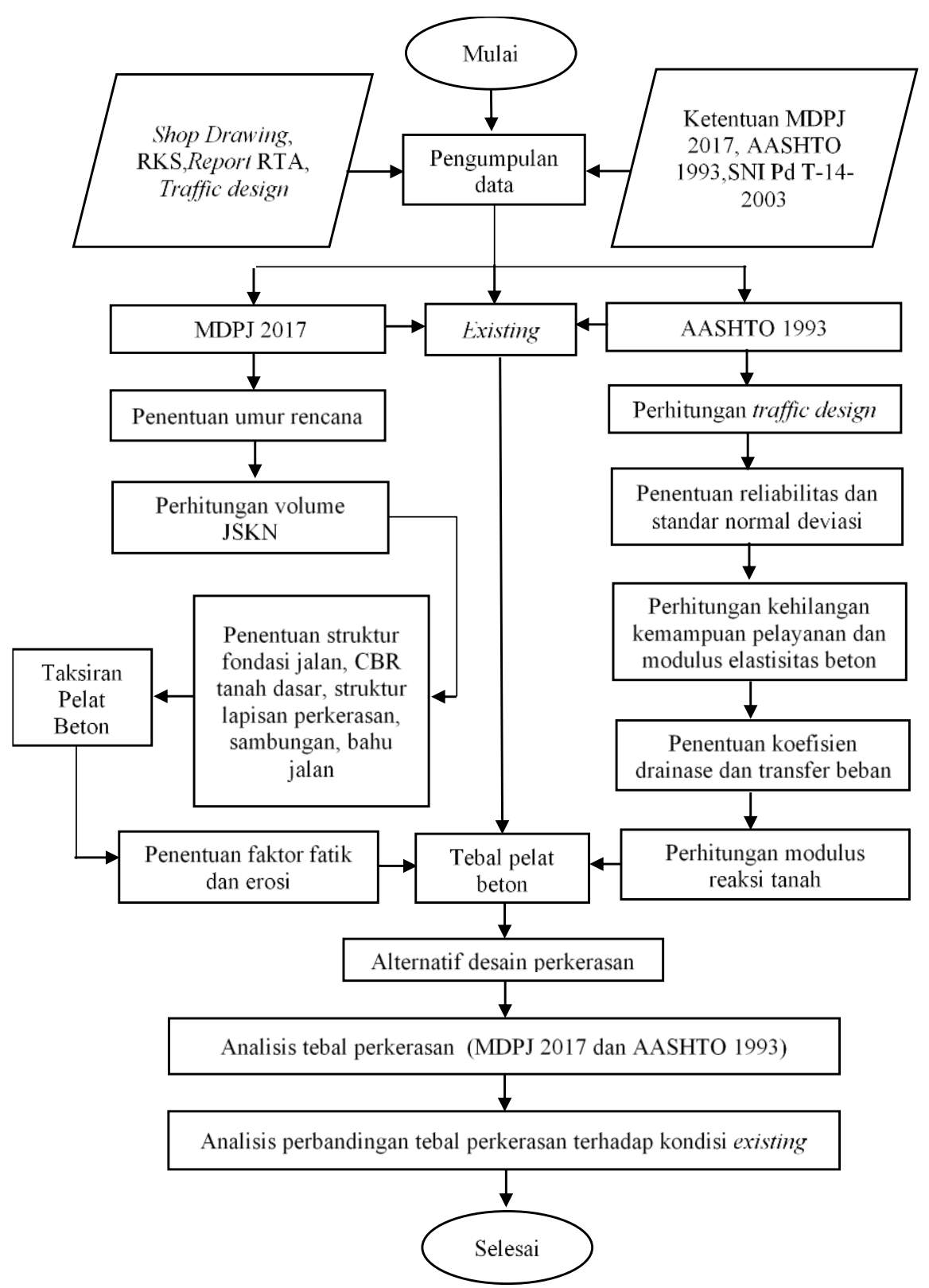

Gambar 1 Diagram alir pelaksanaan penelitian 
Analisis desain perencanaan tebal perkerasan berdasarkan metode MDPJ 2017 meliputi analisis tanah dasar, pondasi bawah, kekuatan lentur, analisis lalu-lintas, bahu, dan sambungan. Adapun parameter yang didapatkan dari data sekunder adalah CBR tanah dasar, distribusi sumbu kendaraan niaga dan jenis/beban sumbu, jenis sambungan, jenis dan tebal pondasi bawah, CBR efektif, faktor keamanan beban $\left(\mathrm{F}_{\mathrm{KB}}\right)$, kuat tarik lentur beton, dan bahu beton.

Variabel yang dihitung dari data sekunder meliputi kerusakan erosi setiap beban sumbu, kerusakan fatik setiap beban sumbu, dan tegangan ekivalen (DitjenBM 2017). Perencanaan tebal perkerasan ditentukan oleh beberapa parameter yaitu faktor erosi setiap jenis sumbu, jumlah repetisi ijin untuk setap sumbu, dan jumlah repitisi ijin setiap beban sumbu.

Analisis desain perencanaan tebal perkerasan berdasarkan metode AASHTO meliputi analisis lalu-lintas, nilai reabilitas, kehilangan kemampuan pelayanan, modulus reaksi tanah dasar, modulus elastisitas beton, kekuatan lentur, koefisien drainase, koefisien transfer beban, dan material konstruksi perkerasan. Analisis tebal perkerasan nya berdasarkan hasil perhitungan dari data sekunder. Variabel yang dihitung dalam perhitungan tebal pelat beton (D) menggunakan metode AASTHO 1993 adalah nilai traffic design $\left(\mathrm{W}_{18}\right)$, kehilangan kemampuan pelayanan $(\Delta$ PSI ) modulus elastistas (Ec), modulus reaksi tanah $(\mathrm{k})$, dan koefisien drainase $(\mathrm{Cd})$.

Hasil perhitungan analisis desain dan tebal perkerasan Jalan Tol Jakarta-Cikampek II elevated menggunakan metode MDPJ 2017 lalu dibandingkan dengan hasil analisis menggunakan AASHTO berdasarkan kondisi exixting.

\section{HASIL DAN PEMBAHASAN}

\section{A. Berdasarkan MDPJ 2017}

\section{Desain Perkerasan Kaku}

Jalan Tol Jakarta-Cikampek II elevated Ruas (Cikunir s/d Karawang Barat (Sta 9+500 s/d Sta 47+500)) termasuk dalam jalan bebas hambatan yang memiliki ruas jalan tol yang melewati 5 wilayah administrasi yaitu Kotamadya Jakarta Timur, Kotamadya Bekasi, Kabupaten Bekasi, Kabupaten Karawang dan Kabupaten Purwakarta. Kondisi Jalan Tol Jakarta-Cikampek memiliki 4 lajur x 3,60 m yang dimulai dari STA $02+050$ s.d STA $37+900$ dan 3 lajur x 3,60 m pada STA 37+900 S.D STA 73+333. Berdasarkan Adendum Andal dan RKL-RPL (Jasamarga 2017) pembangunan Jalan Tol Jakarta-Cikampek sepanjang $73 \mathrm{~km}$ disetujui oleh Menteri Pekerjaan Umum melalui Surat No. KL.0302-MN/130 tanggal 17 Maret 1993.

Pengembangan Jalan Tol JakartaCikampek II elevated dibangun di atas median Jalan Tol Jakarta-Cikampek (eksisting) dari simpang susun ruas Cikunir sampai Karawang Barat sepanjang 36,84 km.Pekerjaan lajur pengganti dilakukan dengan menggeser lajur ke arah luar dengan mengganti bahu jalan selebar 6,1 m (penggeseran lajur 3,6 $\mathrm{m}+$ bahu 2,5 m). Data geometrik jalan jalan tol Jakarta-Cikampek disajikan pada Tabel 1. Kebutuhan beton rigid pada pekerjaan perkerasan kaku pada tahap konstruksi pembuatan lajur pengganti disajikan pada Tabel 2. 
JSIL JURNAL TEKNIK SIPILDAN LINGKLINGAN | Val. 75 №. QI, April ZOZQ

Tabel 1 Geometrik Jalan Tol Jakarta-Cikampek

\begin{tabular}{lcc}
\hline \multicolumn{1}{c}{ Variabel } & Jalan Utama & Ramp \\
\hline Lebar Lajur & $2 \times(4 \times 3,6 \mathrm{~m})$ & $2 \times 3,6 \mathrm{~m}$ \\
Lebar Bahu Jalan & $2,5 \mathrm{~m}$ & $2,5 \mathrm{~m}$ \\
Lebar Bahu Dalam & $1 \mathrm{~m}$ & $1 \mathrm{~m}$ \\
Kemiringan Melintang & $2 \%$ & $2 \%$ \\
Kemiringan Bahu & $2 \%$ & $2 \%$ \\
Kecepatan Rencana & $120 \mathrm{~km} / \mathrm{jam}$ & $40 \mathrm{~km} / \mathrm{jam}$ \\
\hline
\end{tabular}

Tabel 2 Kebutuhan Beton Rigid

\begin{tabular}{|c|c|c|c|c|c|}
\hline \multirow[b]{2}{*}{ Zona } & \multirow[b]{2}{*}{ Area } & \multirow{2}{*}{$\begin{array}{c}\text { Volume } \\
\text { Beton } \\
\left(\mathrm{m}^{3}\right)\end{array}$} & \multicolumn{2}{|c|}{ Durasi } & \multirow{2}{*}{$\begin{array}{l}\text { Kapasitas } \\
\text { Produksi } \\
\left.\text { ( } \mathrm{m}^{3} / \mathrm{jam}\right)\end{array}$} \\
\hline & & & Jam & Bulan & \\
\hline 2 & Cikunir s.d Bekasi Barat & 16661,20 & 12 & 3 & 50 \\
\hline 3 & Bekasi Barat s.d Bekasi Timur & 19670,40 & 12 & 3 & 50 \\
\hline 4 & Bekasi Timur s.d Tambun & 22846,40 & 12 & 3 & 50 \\
\hline 5 & Tambun s.d Cibitung & 17274 & 12 & 3 & 50 \\
\hline 6 & Cibitung s.d Cikarang Utama & $23,849,60$ & 12 & 3 & 50 \\
\hline 7 & Cikarang Utama s.d Cikarang Barat & $15,156,80$ & 12 & 3 & 50 \\
\hline 8 & Cikarang Barat s.d Cibatu & 17608,40 & 12 & 3 & 50 \\
\hline 9 & Cibatu s.d Cikarang Timur & 13652 & 12 & 3 & 50 \\
\hline 10 & Cikarang Timur s.d Karawang Barat & 55779,20 & 12 & 3 & 50 \\
\hline
\end{tabular}

\section{Umur Rencana, Volume Kelompok Sumbu Kendaraan Niaga}

Umur rencana yang digunakan dalam desain perkerasan kaku disesuaikan dengan jenis dan fungsi jalan (DitjenBM 2017). Pekerjaan pembuatan lajur pengganti Jalan Tol JakartaCikampek tergolong jenis pekerjaan pelebaran jalan, sehingga umur rencana untuk pelebaran jalan (rekonstruksi) mengacu pada MDPJ 2017 yaitu 40 tahun. Pertumbuhan lalu lintas selama umur rencana berdasarkan data laju pertumbuhan lalu lintas sebesar $5 \%$ dan faktor pertumbuhan kumulatif (R) sebesar 40,4 selama umur rencana. Berdasarkan distribusi beban kelompok sumbu kendaraan niaga berat (HVAG), jenis kendaraan yang terbagi menjadi golongan I, II, III, IV, V dengan data lalu lintas tahunan yang disajikan pada
Lampiran 2 diperoleh jumlah sumbu kendaraan niaga harian sebesar 9184 buah dengan jumlah sumbu STRT 2078,5 buah, STRG 3315,526 buah, STdRT 1035,826 buah, STdRG 2483,808 buah,dan STrRG 269,983 buah.

Dengan menggunakan persamaan (4) dan (5) diperoleh jumlah sumbu kendaraan niaga selama umur rencana sebesar 13,3 x $10^{7}$ dan jumlah sumbu kendaraan niaga rencana dengan faktor pengaman 0,7 sebesar $9,13 \times 10^{7}$. Total repitisi yang terjadi sebesar $1,72 \times 10^{7}$. Proporsi sumbu yang digunakan dalam perhitungan distribusi sumbu yaitu STRT $55,8 \%$, STRG 26,4\%, STdRT 4,3\%, STdRG 12,2\%, dan STrRG 1,3\% serta beban pada kondisi beban aktual (DitjenBM 2017). 


\section{Struktur Pondasi Jalan, Daya Dukung, dan Struktur Lapisan Perkerasan}

Lapis pondasi dan pondasi bawah berupa lean concrete $100 \mathrm{~mm}$ dan drainage layer $150 \mathrm{~mm}$ (Jasamarga 2017). Tipe material lean concrete yang digunakan adalah subbase yang termasuk unbound granular materials dengan LS = 1.0-3.0. Lapisan agregat kelas A merupakan lapisan pondasi (base course) dan lean concrete merupakan lapisan beton kurus sebagai lapisan untuk hamparan lapisan beton utama (DitjenBM 2017). Berdasarkan ringkasan uji tanah dan perencanaan analisis daya dukung tanah dasar dan analisis settlement dan konsolidasi ditetapkan CBR 6,07 \% dengan nilai k 170 pci. Berdasarkan bagan desain fondasi jalan minimum, struktur pondasi dengan perbaikan tanah dasar berupa stabilasi semen atau material timbunan pilihan dengan pemadatan lapisan $\leq 200 \mathrm{~mm}$.

Kondisi CBR $6 \%$ menyebabkan perbaikan tanah dasar struktur pondasi pada perkerasan kaku sebesar $300 \mathrm{~mm}$ dengan material perbaikan tanah dasar berupa stabilisasi semen. Berdasarkan bagan desain perkerasan kaku untuk jalan dengan beban lalu lintas berat diperoleh struktur perkerasan tebal pelat beton 305 $\mathrm{mm}$, lapis pondasi LMC (lean concrete) $100 \mathrm{~mm}$, dan lapis drainase (drainage layer) $150 \mathrm{~mm}$ dengan kondisi jumlah kendaraan niaga rencana sebesar $9,13 \mathrm{x}$ $10^{7}$ dan desain perkerasan menggunakan sambungan dan ruji (dowel) serta bahu beton (tied shoulder).

\section{Sambungan, Bahu Jalan}

Pekerjaan lajur pengganti Jalan Tol Jakarta-Cikampek ini menggunakan ruji (dowel) yang digunakan pada transverse joint untuk mencegah pumping dan faulting pada slab beton dengan diameter $32 \mathrm{~mm}$, jarak antar dowel $30 \mathrm{~cm}$, dengan panjang dowel 60 $\mathrm{cm}$. Fungsi utama dowel adalah untuk menyalurkan muatan/beban di sebuah joint / sendi tanpa membatasi pergerakan joint yang disebabkan oleh faktor kontraksi termal dan susut muai beton (DepKimPrasWil 2003). Tie bar juga digunakan pada perencanaan penulangan dengan diamter $32 \mathrm{~cm}$, jarak antar tie bar $30 \mathrm{~cm}$ dengan panjang $80 \mathrm{~cm}$. Untuk bahu jalan pada perkerasan digunakan juga bahu beton aspal (AC) yang diperkeras dengan lapis pondasi $100 \mathrm{~mm}$ dan lapis drainase $150 \mathrm{~mm}$.

\section{Tebal Pelat Beton}

Berdasarkan struktur perkerasan, diperoleh tebal pelat beton $305 \mathrm{~mm}$, lapis fondasi LMC (lean concrete) $100 \mathrm{~mm}$, dan lapis drainase (drainage layer) 150 $\mathrm{mm}$. Setelah dilakukan analisis fatik dan erosi yang disajikan pada Tabel 3, besarnya persentase yang diakibatkan fatik sebesar $66,72 \%<100 \%$ dan persentase yang diakibatkan erosi sebesar $40,28 \%<100 \%$. Hal ini menunjukkan kekuatan jalan dengan tebal pelat beton $305 \mathrm{~mm}$ aman terhadap retak fatik dan kerusakan erosi berdasarkan komposisi lalu lintas selama umur rencana. Retak fatik (lelah) adalah kerusakan material yang diakibatkan oleh adanya tegangan yang berfluktuasi, yang besarnya lebih kecil dari tegangan tarik maksimum maupun tegangan luluh material yang diberikan beban konstan (DepKimPrasWil 2003). Kerusakan erosi adalah terjadinya erosi pada pondasi bawah atau tanah dasar yang diakibatkan oleh lendutan berulang pada sambungan dan tempat retak yang direncanakan. Tebal pelat rencana adalah tebal taksiran yang paling kecil yang mempunyai total fatik dan atau total kerusakan erosi lebih kecil atau sama dengan $100 \%$ (DepKimPrasWil 2003).

Penentuan tegangan setara dan faktor erosi dalam analisis fatik dan erosi disajikan pada Tabel 4. Faktor ratio tegangan merupakan hasil tegangan setara yang berbanding terbalik terhadap kuat lentur beton (DepKimPrasWil2003). 
Besarnya faktor ratio tegangan pada sumbu adalah STRT 0,10, STRG 0,18, STdRG 0,16, dan STrRG 0,13. Berdasarkan data sekunder laporan analisis perkerasan besarnya kuat lentur beton yang digunakan adalah 4,5 Mpa, kuat tekan beton sebesar $35 \mathrm{Mpa}$, dan modulus elastisitas beton(Ec) sebesar 4020000 psi.

Tabel 3 Hasil Perhitungan Analisis Fatik dan Erosi

\begin{tabular}{|c|c|c|c|c|c|c|c|c|c|}
\hline \multirow{2}{*}{$\begin{array}{c}\text { Jenis } \\
\text { Sumbu }\end{array}$} & \multirow{2}{*}{$\begin{array}{c}\text { Beban } \\
\text { Sumbu } \\
(\mathrm{KN})\end{array}$} & \multirow{2}{*}{$\begin{array}{c}\text { Koef } \\
\text { Beban } \\
\text { Rencana }\end{array}$} & \multirow{2}{*}{$\begin{array}{c}\text { Beban } \\
\text { Rencana } \\
\text { Per Roda } \\
(\mathrm{KN})\end{array}$} & \multirow{2}{*}{$\begin{array}{c}\text { Repetisi } \\
\text { yang } \\
\text { terjadi }\end{array}$} & \multirow{2}{*}{$\begin{array}{c}\text { Faktor } \\
\text { Tegangan } \\
\text { dan Erosi }\end{array}$} & \multicolumn{2}{|c|}{$\begin{array}{c}\text { Analisis Retak } \\
\text { Fatik (Lelah) }\end{array}$} & \multicolumn{2}{|c|}{ Analisis Erosi } \\
\hline & & & & & & RI & $\begin{array}{l}\mathrm{PR} \\
(\%)\end{array}$ & RI & $\begin{array}{l}\text { PR } \\
(\%)\end{array}$ \\
\hline \multirow{4}{*}{ STRT } & 19,6 & 0,55 & 10,8 & $4,26 \times 10^{6}$ & \multirow{4}{*}{$\begin{array}{l}\mathrm{TE}=0,47 \\
\mathrm{FRT}=0,10 \\
\mathrm{FE}=1,3\end{array}$} & TT & 0 & TT & 0 \\
\hline & 19,6 & 0,55 & 10,8 & $4,26 \times 10^{6}$ & & $\mathrm{TT}$ & 0 & $\mathrm{TT}$ & 0 \\
\hline & 81,4 & 0,55 & 44,8 & $3,37 \times 10^{5}$ & & $\mathrm{TT}$ & 0 & TT & 0 \\
\hline & 88,3 & 0,55 & 48,5 & $3,37 \times 10^{5}$ & & TT & 0 & TT & 0 \\
\hline \multirow{4}{*}{ STRG } & 81,4 & 0,275 & 22,4 & $1,6 \times 10^{5}$ & \multirow{4}{*}{$\begin{array}{l}\mathrm{TE}=0,83 \\
\mathrm{FRT}=0,18 \\
\mathrm{FE}=1,91\end{array}$} & $\mathrm{TT}$ & 0 & TT & 0 \\
\hline & 88,3 & 0,275 & 24,3 & $1,6 \times 10^{5}$ & & $\mathrm{TT}$ & 0 & TT & 0 \\
\hline & 156,9 & 0,275 & 43,1 & $7 \times 10^{4}$ & & $\mathrm{TT}$ & 0 & TT & 0 \\
\hline & 215,7 & 0,275 & 59,3 & $6,9 \times 10^{5}$ & & $9 \times 10^{5}$ & 66,72 & $15 \times 10^{5}$ & 40,03 \\
\hline \multirow{3}{*}{ STdRG } & 156,9 & 0,1375 & 21,6 & $1,86 \times 10^{5}$ & $\mathrm{TE}=0,76$ & TT & 0 & TT & 0 \\
\hline & 215,7 & 0,1375 & 29,7 & $9,09 \times 10^{4}$ & $\mathrm{FRT}=0,17$ & TT & 0 & $\mathrm{TT}$ & 0 \\
\hline & 294,2 & 0,1375 & 40,5 & $1,89 \times 10^{4}$ & $\mathrm{FE}=2,13$ & $\mathrm{TT}$ & 0 & $6 \times 10^{6}$ & 0,19 \\
\hline \multirow{4}{*}{ STrRG } & 392,3 & 0,083 & 32,7 & $3,49 \times 10^{3}$ & $\mathrm{TE}=0,56$ & $\mathrm{TT}$ & 0 & $6 \times 10^{6}$ & 0,05 \\
\hline & & & & & $\mathrm{FRT}=0,12$ & & & & \\
\hline & & & & & $\mathrm{FE}=2,29$ & & & & \\
\hline & & & Total & & & & 66,72 & & 40,28 \\
\hline
\end{tabular}

Tabel 4 Penentuan Tegangan Setara dan Faktor Erosi

\begin{tabular}{|c|c|c|c|c|c|c|c|c|c|}
\hline \multirow{2}{*}{$\begin{array}{l}\text { Tebal } \\
\text { Slab } \\
(\mathrm{mm})\end{array}$} & \multirow{2}{*}{$\begin{array}{c}\text { CBR } \\
\text { Effektif } \\
\text { Tanah } \\
\text { Dasar } \\
(\%)\end{array}$} & \multicolumn{4}{|c|}{ Tegangan Setara (TE) } & \multicolumn{4}{|c|}{$\begin{array}{c}\text { Faktor Erosi (FE) } \\
\text { Dengan Ruji (Dowel) }\end{array}$} \\
\hline & & STRT & STRG & STdRG & STrRG & STRT & STRG & STdRG & STrRG \\
\hline \multirow{3}{*}{305} & 5 & 0,46 & 0,81 & 0,76 & 0,55 & 1,29 & 1,89 & 2,13 & 2,30 \\
\hline & 6,07 & 0,47 & 0,83 & 0,76 & 0,56 & 1,3 & 1,91 & 2,13 & 2,29 \\
\hline & 10 & 0,40 & 0,77 & 0,70 & 0,52 & 1,27 & 1,87 & 2,07 & 2,22 \\
\hline
\end{tabular}

\section{B. Berdasarkan AASHTO 1993 Analisis Lalu lintas}

Umur rencana yang digunakan dalam perencanaan adalah 20 tahun. Umur rencana rigid pavement (perkerasan kaku) umumnya diambil 20 tahun untuk konstruksi baru (AASHTO 1993). Berdasarkan pertumbuhan lalu lintas tahunan, faktor distribusi lajur $\left(\mathrm{D}_{\mathrm{L}}\right)$ dalam perencanaan adalah 0,9 karena ada
2 jumlah lajur setiap arah pada pembuatan lajur pengganti dan faktor distribusi arah $\left(\mathrm{D}_{\mathrm{D}}\right)$ sebesar 0,5. Nilai faktor distribusi arah $\left(\mathrm{D}_{\mathrm{D}}\right)$ sebesar 0,3 0,7 (AASHTO 1993).

Jumlah lalu lintas kumulatif selama umur rencana (Wt) sebesar 256.081.379,842 ESAL yang diperoleh dari data LHR dengan faktor distribusi arah 0,5 dan faktor distribusi lajur 
rencana 0,9. Lalu lintas yang digunakan dalam perencanaan tebal perkerasan adalah lalu lintas kumulatif selama umur rencana (AASHTO 1993). Hasil perhitungan Wt disajikan pada Tabel 5.

\section{Reliabilitas, Standar Normal Deviasi} Jalan Tol Jakarta-Cikampek II elevated termasuk jalan tol dengan konstruksi baru (untuk daerah widening), sehingga berdasarkan AASHTO 1993 (recommended reability values) jalan tol berada pada koridor jalan bebas hambatan daerah rural dengan angka reliabilitas antara 85-99. Dengan demikian angka reliabilitas yang direkomendasikan dan digunakan dalam perhitungan adalah 90. Nilai 90 relatif merupakan angka yang konservatif terhadap tabel nilai $\mathrm{R}$ berdasarkan fungsi jalan (AASHTO 1993). Angka reliabilitas 90 yang diperoleh menunjukkan standar normal deviasi $\left(\mathrm{Z}_{\mathrm{R}}\right)$ sebesar -1,282 dengan probabilitas atau kemungkinan yang terjadi cacat sebesar $10 \%$. Berdasarkan AASHTO (1993) road test merekomendasikan angka standar deviasi (So) sebesar 0,35 untuk perkerasan kaku. Nilai So menunjukkan variasi atau deviasi yang menghasilkan perkerasan yang lebih tebal dan sesuai dengan kondisi jalan bebas hambatan pada pembangunan Tol (AASHTO 1993).

\section{Kehilangan Kemampuan Pelayanan, Koefisien Transfer Beban}

Kehilangan kemampuan pelayanan jalan menunjukan initiail serviceability $\quad\left(\mathrm{p}_{0}=4,5\right), \quad$ terminal serviceability index jalur utama (major highways $) \quad\left(\mathrm{p}_{\mathrm{t}}=2,5\right), \quad$ terminal serviceability index jalan lalu-lintas rendah $\left(\mathrm{p}_{\mathrm{t}}=2,0\right)$ (AASHTO 1993). Jalan tol Jakarta-Cikampek II elevated termasuk terminal seviceability index jalur utama (major highways) dengan $\mathrm{p}_{\mathrm{t}}=2$, sehingga, kehilangan kemampuan pelayanan jalan ( $\triangle \mathrm{PSI})$ sebesar 2 dengan kondisi initiail serviceability $\left(\mathrm{p}_{0}=4,5\right)$. Indeks permukaan awal (Po) menunjukkan indeks permukaan jalan yang baru dibuka untuk umum, sedangkan indeks permukaan akhir $(\mathrm{Pt})$ menunjukkan indeks permukaan terkecil yang diperbolehkan atau akhir dari fungsi pelayanan didasarkan pada indeks terendah yang dapat ditoleransi sebelum rehabilitasi yang memerlukan overlay atau rekonstruksi (AASHTO 1993).

Tabel 5 Hasil Perhitungan Wt

\begin{tabular}{lrrrrrr}
\hline Jenis Kendaraan & $\begin{array}{c}\text { LHR } \\
\text { (ESA/tahun) }\end{array}$ & VDF & DD & DL & W18 (ESAL) & $\begin{array}{c}\text { Wt } \\
(\text { ESAL) }\end{array}$ \\
\hline Golongan I & 519,625 & 1,0 & 0,5 & 0,9 & 233,831 & \\
Golongan II & 1035,826 & 36,9 & 0,5 & 0,9 & 17199,891 & \\
Golongan III & 1240,450 & 28,9 & 0,5 & 0,9 & 16132,052 & $256.081 .379,842$ \\
Golongan IV & 207,532 & 13,6 & 0,5 & 0,9 & 1270,096 & \\
Golongan V & 269,983 & 30,3 & 0,5 & 0,9 & 3681,218 & \\
\hline
\end{tabular}

AASHTO (1993) menyatakan koefisien transfer beban untuk AC/CRCP sebesar 2,2-2,6 dan perkerasan beton tak bertulang bersambungan (JPCP) dan beton bertulang bersambungan menunjukkan angka koefisien transfer beban sebesar 2,5-3,1 serta perkerasan beton bertulang bersambungan (CRCP) sebesar 2,3-3,9. Nilai koefisien transfer beban yang digunakan dalam perhitungan 
sebesar 2,6 dengan kondisi perencanaan jalan tol Jakarta-Cikampek II elevated memakai tied shoulder dan sambungan beton memakai ruji (dowel) dan adanya penanganan crack dan overlay bila sudah mencapai ESAL sesuai umur rencana.

\section{Koefisien Drainase, Modulus Elastisitas Beton}

Berdasarkan data sekunder laporan analisa perkerasan, rata-rata hujan per hari ditentukan selama 3 jam dengan rata-rata jumlah hari hujan sebesar 137 hari per tahun. Koefisien pengaliran yang digunakan adalah 0,825 pada kondisi permukaan tanah fungsi jalan beton dan jalan aspal. Nilai koefisien pengaliran $(\mathrm{C})$ kondisi permukaan tanah fungsi jalan beton dan aspal ialah pada rentang 0,70-0,95 (AASHTO1993). Nilai 0,825 merupakan angka yang konservatif terhadap nilai koefisien pengaliran $(\mathrm{C})$ berdasarkan fungsi jalan dan kondisi permukaan tanah (AASHTO 1993). Faktor air hujan yang akan masuk ke pondasi jalan $\left(\mathrm{W}_{\mathrm{L}}\right)$ berdasarkan koefisien pengaliran yang telah didapat sebesar $17 \%$. Persentase hari efektif hujan dalam setahun ( $\left.\mathrm{P}_{\text {heff }}\right)$ sebesar $0,821 \%$ terhadap waktu struktur perkerasan terkena air hingga tingkat kelembabannya mendekati jenuh air kurang dari $1 \%$. Diperoleh koefisien drainase $(\mathrm{Cd})$ sebesar 1,15 dalam kondisi baik. Berdasarkan data sekunder laporan analisa perkerasan, kekuatan lentur beton (Sc') sebesar 640 psi. Kuat lentur beton ditentukan berdasarkan tegangan tarik pada saat beton mulai retak (AASHTO 1993). Kuat tekan beton (fc') sebesar 4977 psi, sehingga diperoleh modulus elastisitas beton (Ec) sebesar 4.020.000 psi.

\section{Modulus Reaksi Tanah Dasar}

Tipe material di bawah pavement beton adalah subbase, maka tipe material yang digunakan unbound granular materials dengan LS $=1,0-3,0$. Digunakan nilai $\mathrm{LS}=1$ dengan CBR sub grade 6,07 \%,
CBR aggregat A $80 \%$, dan CBR kombinasi $11,21 \%$. Nilai k dengan loss of support (LS) menunjukan potensial LS yang muncul dari erosi subbase dan perbedaan vertikal pergerakan tanah (AASHTO 1993). Modulus reaksi tanah dasar sebesar 867 pci yang diperoleh dari nilai realient (elastic) modulus (MR) sebesar 16815 yang berbanding terbalik terhadap faktor pembagi 19,4. Modulus reaksi tanah dasar efektif sebesar 170 pci yang diperoleh dari grafik hubungan $\mathrm{k}$ efektif dengan modulus reaksi tanah dasar (modulus of subgrade reaction). Unbound granular materials merupakan bahan yang terdiri dari batu berbutir dan biasa digunakan dalam lapisan pondasi (lean concrete) (AASHTO 1993).

\section{Tebal Pelat Beton}

Berdasarkan jumlah lalu lintas kumulatif selama umur rencana diperoleh $\log _{10} \mathrm{~W}_{18}$ sebesar 8,4 sehingga dengan menggunakan persamaan 10 diperoleh tebal pelat beton sebesar $320 \mathrm{~mm}$. Perhitungan tebal pelat beton menggunakan data parameter perencanaan tebal pelat beton disajikan pada Tabel 6.

\section{Perbandingan dengan kondisi aktual}

Tebal pelat beton yang diperoleh dengan menggunakan MDPJ 2017 sebesar $305 \mathrm{~mm}$ dan AASHTO 1993 sebesar 320 $\mathrm{mm}$. Terjadinya perbedaan nilai tebal pelat beton disebebkan adanya perbedaan paramater dalam perhitungan. Paramater yang digunakan pada MDPJ 2017 adalah umur rencana, volume JSKN, struktur fondasi jalan, CBR tanah dasar, struktur lapisan perkerasan, sambungan, bahu jalan, analisa faktor fatik dan erosi. Parameter yang digunakan pada AASHTO 1993 adalah analisis lalu intas, nilai reliabilitas, standar normal deviasi, kehilangan kemampuan pelayanan, modulus elastisitas beton, koefisien drainase, transfer beban, dan modulus reaksi tanah. 


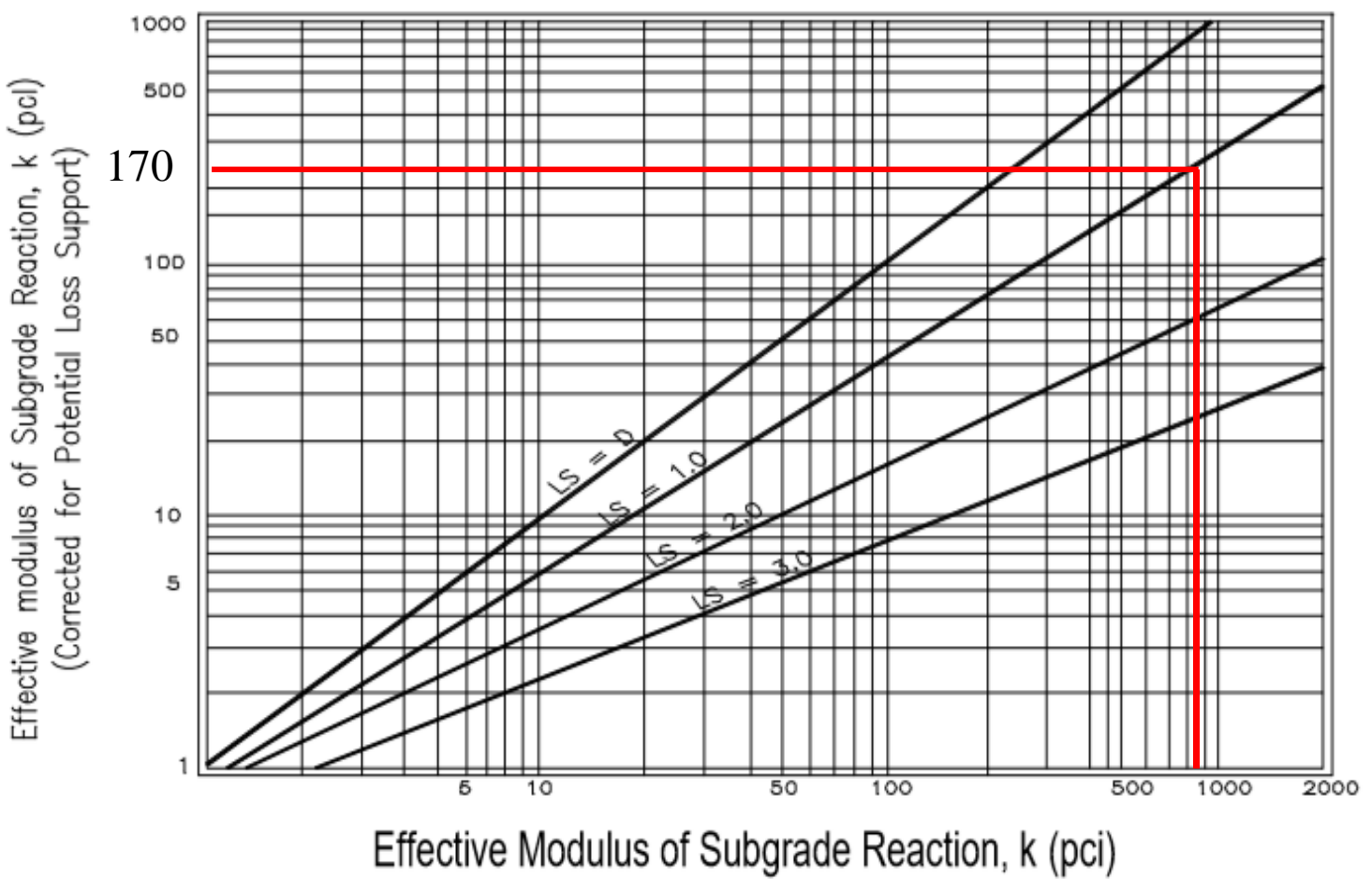

Gambar 2 Grafik hubungan k efektif dengan modulus of subgrade reaction

Tabel 6 Data Parameter Perencanaan Perkerasan Kaku

\begin{tabular}{clccc}
\hline No & \multicolumn{1}{c}{ Parameter } & Simbol & Nilai & Satuan \\
\hline 1 & Umur Rencana & & 20 & Tahun \\
2 & W18 Kumulatif & $\mathrm{Wt}$ & $256.081 .379,842$ & ESAL \\
3 & CBR Sub Grade & $\mathrm{CBR}$ & 6,07 & $\%$ \\
4 & CBR Aggregat A & $\mathrm{CBR}$ & 80 & $\%$ \\
5 & CBR Kombinasi & $\mathrm{CBR}$ & 11,21 & $\%$ \\
6 & Reasilient (Elastic) Modulus & $\mathrm{MR}$ & 168115 & $\mathrm{pci}$ \\
7 & Modulus Reaksi Tanah & $\mathrm{k}$ & 867 & $\mathrm{pci}$ \\
8 & Eff. Modulus Reaksi Tanah & $\mathrm{k}$ & 170 & $\mathrm{pci}$ \\
& Dasar & $\mathrm{Sc}$ & 663 & $\mathrm{psi}$ \\
9 & Kekuatan Lentur & $\mathrm{fc}$ & 4977 & $\mathrm{psi}$ \\
10 & Kuat Tekan Beton & $\mathrm{Ec}$ & 4020000 & $\mathrm{psi}$ \\
11 & Modulus Elastisitas Beton & $\mathrm{Cd}$ & 1,15 & \\
12 & Koefisien Drainase & $\mathrm{J}$ & 2,5 & \\
13 & Transfer Beban & $\mathrm{R}$ & 90 & \\
14 & Reabilitas & $\mathrm{Z}$ & $-1,282$ & \\
15 & Normal Standar Deviasi & $\mathrm{So}$ & 0,35 & \\
16 & Combine Standart Error & $\mathrm{Po}$ & 4,5 & \\
17 & Innitial Service Ability Index & $\mathrm{Pt}$ & 2,5 & \\
18 & Terminal Service Index & Po-Pt & 2 & \\
19 & MPSI & & & \\
\hline & & &
\end{tabular}

Nilai tebal pelat beton yang eksisting sudah dilakukan perhitungan dan diperoleh dengan MDPJ 2017 dan analisis perencanaan perkerasan komposit AASHTO 1993 juga berbeda dengan (perkerasan kaku dan perkerasan lentur). kondisi eksisting. Tebal pelat beton kondisi Berdasarkan data sekunder laporan analisa eksisiting sebesar $300 \mathrm{~mm}$. Hal ini perkerasan, tebal pelat beton sebelum disebabkan tebal pelat beton pada kondisi dilakukan perhitungan dengan perkerasan 
komposit adalah sebesar $330 \mathrm{~mm}$. Hasil tebal pelat beton yang diperoleh dengan menggunakan MDPJ 2017 dan AASHTO 1993, serta kondisi eksisting disajikan pada Tabel 7.

Tabel 7 Nilai Tebal Pelat Beton

\begin{tabular}{lc}
\hline Parameter & Tebal Pelat Beton $(\mathrm{mm})$ \\
\hline MDPJ 2017 & 305 \\
AASHTO 1993 & 320 \\
Eksisting & 300 \\
\hline
\end{tabular}

\section{KESIMPULAN}

Simpulan yang dapat ditarik dari penelitian ini adalah alternatif desain pada perencanaan tebal perkerasan kaku lajur pengganti proyek pembangunan jalan tol Jakarta-Cikampek II dengan menggunakan metode MDPJ 2017 diperoleh parameter volume jumlah sumbu kendaraan niaga harian 9184 buah, jumlah sumbu kendaraan niaga sebesar $13,3 \times 10^{7}$ dan jumlah sumbu kendaraan niaga rencana sebesar 9,13 x $10^{7}$ serta kerusakan fatik sebesar $66,72 \%$ $<100 \%$ dan persentase yang diakibatkan erosi sebesar 40,28\%<100\%. Dengan metode AASHTO 1993 diperoleh parameter jumlah lalu lintas kumulatif selama umur rencana (Wt) sebesar 256.081.379,842 ESAL.

Tebal pelat beton pada perencanaan tebal perkerasan kaku lajur pengganti proyek pembangunan jalan tol Jakarta-Cikampek II elevated dengan menggunakan metode MDPJ 2017 sebesar $305 \mathrm{~mm}$ dan metode AASHTO 1993 sebesar $320 \mathrm{~mm}$ dengan lapis pondasi (lean concrete) $100 \mathrm{~mm}$ dan lapis drainase (agregate A) $150 \mathrm{~mm}$.

Perencanaan tebal pelat beton dengan menggunakan metode MDPJ 2017 dan AASHTO 1993 memiliki perbedaan dengan kondisi perencanaan existing jalur pengganti jalan tol JakartaCikampek II elevated yang disebabkan tebal pelat beton pada kondisi eksisting sudah dilakukan perhitungan dan analisis perencanaan perkerasan komposit (perkerasan kaku dan perkerasan lentur) dan adanya perbedaan parameter dalam perhitungan. Tebal pelat beton sebelum dilakukan perhitungan dengan perkerasan komposit adalah sebesar 330 $\mathrm{mm}$ dan tebal pelat beton sesudah dilakukan perhitungan dengan perkerasan komposit sebesar $300 \mathrm{~mm}$.

\section{DAFTAR PUSTAKA}

[AASHTO] American Association of State Highway Officials. 1993. Guide for Design of Pavement Structures. Washington DC (US): AASHTO.

Apriyono A., 2009. Analisis penyebab tanah longsor di Kalitlaga Banjarnegara. Jurnal Dinamika 5(1), pp. 1-5.

Aris MNA, Simbolan G, Setiadji BH, Supriyono. 2015. Analisis Perbandingan Perencanaan Tebal Perkerasan Jalan Lentur Menggunakan Beberapa Metode Bina Marga. (Studi Kasus: Ruas Jalan Piringsurat - Batas Kedu Timur) . Jurnal Karya Teknik Sipil. 4(4): $380-393$.

Asiyanto. 2010. Metode Konstruksi Proyek Jalan . Jakarta (ID) : UIPress.

[ASTM] American Society for Testing and Materials. 2008. Test Methods for Dowel-Bearing Strength Assessment of Wood: Experimental and Numerical Investigations. Philadelphia (US): American Society for Testing and Materials D5764.

Bolla ME, Messah, Koreh MM. 2013. Analisis daerah rawan kecelakaan lalu lintas (Studi Kasus Ruas Jalan Timor Raya Kota Kupang). Jurnal Teknik Sipil. 2 (2) : 147-156. 
[BSN] Badan Standardisasi Nasional. 2003. Pedoman Perencanaan Perkerasan Jalan Beton Semen. SNI Pd T-14-2003. Jakarta (ID) : BSN.

[DitjenBM] Direktorat Jenderal Bina Marga. 2006. Perencanaan Sistem Drainase Jalan. Jakarta (ID) : Kementerian Pekerjaan Umum Republik Indonesia.

[DitjenBM] Direktorat Jenderal Bina Marga. 2017. Manual Desain Perkerasan Jalan. Jakarta (ID) : Kementerian Pekerjaan Umum Republik Indonesia.

[DepKimPrasWil] Departemen Permukiman dan Prasarana Wilayah. 2003. Perencanaan dan Pelaksanaan Perkerasan Jalan Beton Semen. Jakarta (ID) : Departemen Permukiman dan Prasarana Wilayah.

[FHWA] Federal Highway Administration. 2006. Geotechnical Aspects of Pavements, Reference Manual/Participant Workbook, Publication No. FHWA NHI050037. Washington DC (US): U.S. Depart. of Transportation Federal Highway Administration.

Gautama G. 2017. Efektivitas Penggunaan Rigid Pavement (Sta 140+ 000 S/D Sta 140+ 400) pada Ruas Jalan Tol BakauheniTerbanggi Besar Provinsi Lampung. TAPAK [Teknologi Aplikasi Konstruksi]. Jurnal Program Studi Teknik Sipil. 6(2) : 175 - 189.

Hadijah, Harizalsyah. 2017. Perencanaan Jalan dengan Perkerasan Kaku Menggunakan Metode Analisa Komponen Bina Marga (Studi Kasus : Kabupaten Lampung Tengah Provinsi Lampung. TAPAK [Teknologi Aplikasi Konstruksi]. Jurnal Program Studi Teknik Sipil. 6 (2) : 140-146.

Hamirhan S. 2005. Konstruksi Jalan Raya. Bandung (ID): Nova.
Hardiyatmo H.C. 2011. Perancangan Perkerasan Jalan dan Penyelidikan Tanah. Yogyakarta (ID): Gadjah Mada University Press.

Huang YH. 2004. Pavement Analysis and Design. Upper Saddle River (US): Pearson Education.

Irawan S, Subagio B, Hariyadi E, Gerardo F. 2017. Evaluasi Struktural Perkerasan Kaku Menggunakan Metoda AASHTO 1993 dan Metoda AUSTROADS 2011 Studi Kasus : Jalan Cakung-Cilincing. Jurnal Teknik Sipil. 24(2): 173-182.

[Jasamarga] PT Jasamarga Jalanlayang Cikampek. 2017. Adendum Andal dan RKL-RPL Pembangunan Jalan Tol Jakarta-Cikampek II Elevated. Jakarta (ID) : PT Jasamarga Jalanlayang Cikampek.

Juniardi YE, Basuki KH. 2010. Analisis arus lalu lintas di simpang tak bersinyal (studi kasus simpang Timoho dan simpang Tunjung kota Yogyakarta). Jurnal Media Komunikasi Teknik Sipil. 18(1): 112.

Kang M, Kim M, Lee J. H. 2010. Analysis of Rigid Pavement Distresses on Interstate Highway Using Decision Tree Algorithms. KSCE Journal of Civil Engineering. 14(2): 123-130.

Mudjanarko S.W. 2009. Analisa Perbandingan Beberapa Metode Perkerasan Beton untuk Jalan Akses Jembatan Suramadu. NEUTRON .9(1): 143 -225.

[NAVFAC] Naval Facilities Engineering Command. 1979. Civil Engineering Pavements, Design Manual 5.4. Alexandria (US): Depart. of The Navy Naval Facilities Engineering Command.

Prima G, Iskandar H, Joewono. 2014. Kajian Nilai Ekivalensi Mobil Penumpang Berdasarkan Data Waktu Antara pada Ruas Jalan Tol. 
Jurnal Jalan-Jembatan. 31 (2) : 7482.

Rompas G, Pangouw JD, Pandaleke, Mangare JB. 2013. Pengaruh Pemanfaatan Abu Ampas Tebu Sebagai Subsitusi Parsial Semen Dalam Campuran Beton Ditinjau Tehadap Kuat Tarik Lentur dan Modulus Elastisitas. Jurnal Sipil Statik. 1 (2): 82-89.

Sianturi NM. 2012. Tinjauan Pengguanaan Balok Pracetak pada Pembangunan Gedung. Jurnal Rancang Sipil. 1 (1) : 10-20.

Sukirman S. 2003. Beton Aspal Campuran Panas. Jakarta (ID): Granit. 
JSIL | Ardiansyah \& Sudibya. : Analisis Perencanaan Tebal Perkerasan Kaku 